\title{
Landscape dynamics and habitat selection by the alien invasive Fallopia (Polygonaceae) in Belgium
}

\author{
Marie-Solange Tiébré, Layla Saad, Grégory Mahy \\ Laboratory of Ecology, Gembloux Agricultural University, Passage des Déportés 2, 5030 Gembloux, Belgium
}

\begin{abstract}
Habitat patch colonization dynamics and distribution patterns were analysed at a landscape scale in four invasive Fallopia (Polygonaceae) species. Fallopia sachalinensis and F. aubertii were uncommon and population expansion was not evident during the three consecutive years of study. The two most widespread species, $F$. japonica and $F . \times$ bohemica displayed similar habitat selection patterns with ruderal and natural/semi-natural forests favoured. The highest densities of $F$. japonica and $F . \times$ bohemica individuals were at the edge of preferred habitat patches with different patterns of edge selection. Linear network played an important role in species invasion, with $71 \%$ of all $F$. japonica and $F$. $\times$ bohemica occurring within a $10 \mathrm{~m}$ buffer of total linear networks (roads, railways, and rivers). However, the buffer represented only $14.5 \%$ of the total landscape surface. The rate of population increase was higher for $F$. japonica $(75.8 \%$ and $35.2 \%$, in 2002 and 2003, respectively) than for $F . \times$ bohemica $(63.6 \%$ and $0 \%$ in 2002 and 2003 , respectively) and was largely the result of intra-patch dynamics with low inter-patch colonization. The total surface area occupied by Fallopia clones in the landscape grew by $34.7 \%$ over 2 years of the study, with comparable area growth means for $F$. japonica and $F . \times$ bohemica $(34.9 \%$ and $34.7 \%$, respectively). The hypothesis that $F . \times$ bohemica exhibits higher invasive dynamics due to both clonal and sexual reproduction was not supported by our results.
\end{abstract}

Keywords : Fallopia ; Habitat selection ; Hybridization ; Invasive plants ; Landscape ; Population dynamics

\section{INTRODUCTION}

Alien species invasions are considered one of the most severe threats to global biodiversity (Vitousek et al. 1997; Wilcove 1998). Invasive species distributions across a landscape result from interactive processes including colonization, competition, extinction and evolution (Huang and Zhang 2007). Analysing the distribution patterns of alien invasive species at a landscape scale is key to establish management priorities for invasion control and habitat protection (Hobbs and Humphries 1995; Collingham et al. 2000; Marvier et al. 2004).

Most research on alien invasive species distributions has focused on the rates of expansion on large-scales (Conolly 1977; Perrins et al. 1993; Godefroid 1996). In addition, ecosystem invasibility has been investigated (Lonsdale 1999; Pyšek and Richardson 2006) but analyses were often conducted at spatial scales too large to provide adequate data on landscape scale habitat selection and the dynamics of habitat patch colonization (Collingham et al. 2000; Wang and Wang 2006; Adriaens et al. 2008) (but see Bímová et al. 2004). The application of habitat selection indices provides a quantitative measure of the relative use of habitats in proportion to their availability (Cock 1978; Buse 1988; Manly et al. 1993; Kamler and Gipson 2000; Duriez et al. 2005; Zimmer and Power 2006).

At a landscape scale, another aspect of invasive species distributions addresses invasion mechanisms along linear networks (communication routes and habitat borders). Communication routes (rivers, roads, and railways) and adjacent vegetation strips are recognized as human disturbance factors substantially affecting the natural landscape (Forman and Alexander 1998; Martinez and Wool 2006). River bank management, and road and rail construction cause considerable alterations to natural communities, such as clearing soil and natural vegetation, increasing light at ground level and modifying drainage (Christen and Matlack 2006; Richardson et al. 2007). Communities subjected to disturbance regimes are dominated by disturbance-tolerant species and are particularly vulnerable to invasion by alien species, which are often well adapted to disrupted environments (Fox and Fox 1986; Panetta and Hopkins 1991; Forman and Alexander 1998; Parendes and Jones 2000; Song et al. 2005). Linear networks may also act as vehicles for subsequent migration into adjacent habitats (Pyšek and Prach 1993; Christen and Matlack 2006; Richardson et al. 2007). 
In the current study, we explored habitat selection and spread dynamics of four clonal alien invasive plant species at a landscape scale in the genus Fallopia Adans. (Polygonaceae), including $F$. japonica (Houtt.) Ronse Decraene, F. sachalinensis (F. Schmidt Petrop.) Ronse Decraene, F. × bohemica (Chrtek et Chrtková) J. P. Bailey, a proposed hybrid between $F$. japonica and $F$. sachalinensis, and the climbing perennial $F$. aubertii (L. Henry) Holub (Syn. F. baldschuanica (Regel) Holub). Species comprising the genus Fallopia originated in Asia and are considered among the most troublesome alien invasive species in Europe and Northern America (Weber 2003). Fallopia japonica and $F$. sachalinensis were introduced to Belgium and its neighbouring countries at the end of the ninetieth century as ornamental species and/or fodder. More recently, F. aubertii was also introduced as an ornamental species (Vanden Berghem 1997; Verloove 2002; Saintenoy-Simon 2003). The status of $F$. × bohemica is still discussed as it is not clear whether the hybrid was produced in situ or was also introduced independently of the parental species (Tiébré et al. 2007b). At the beginning of the twentieth century, plants remained uncommon until 1945, when various accidental introductions into natural habitats resulted in species expansion (Godefroid 1996; Vanden Berghem 1997). Fallopia taxa are now widely naturalized and some are a threat to native ecosystems. Invasive alien Fallopia are extremely difficult to control by both manual and chemical methods. The combination of successful vegetative propagation (Bímová et al. 2003; Pashley et al. 2007), high competitive capacity (Mandák et al. 2004), hybridization and polyploidization (Tiébré et al. 2007a) and sexual reproduction (Child and Wade 2000; Hathaway 2000; Tiébré et al. 2007b) certainly contribute to the success of these invasive plants.

Vegetative regeneration has been recognized as the primary mode of reproduction in Fallopia outside their native range (Beerling et al. 1994; Child and Wade 2000; Weber 2003). This was due to the male sterility of the most widespread taxa $F$. japonica. However, multiple interspecific hybridizations and polyploid formation have been described among the species (Bailey and Stace 1992; Bailey 2003; Mandák et al. 2004; Tiébré et al. 2007a, b), demonstrating the presence of sexual reproduction within the species complex. Fallopia $\times$ bohemica is a presumed hybrid between $F$. japonica and $F$. sachalinensis. Hybridization has served to increase the genetic variability in $F$. $\times$ bohemica compared to the parental species, and enhance propagule pressure via the production of viable hybrid seed and effective seed dispersal mechanisms. In addition, $F$. $\times$ bohemica grows and spreads faster compared to its progenitor species (Bímová et al. 2003; Mandák et al. 2004). The differences in genotypic diversity, reproductive success and regeneration characteristics in $F . \times$ bohemica may induce different invasion rates and distribution dynamics at the landscape scale compared with other Fallopia species. Hybridization is also frequent between $F$. aubertii and other introduced Fallopia taxa (Tiébré et al. 2007b), but the resulting hybrids do not establish in the nature (Tiébré et al 2007b).

The spatial distribution of Fallopia was mapped on both a continent (Europe) (Jalas and Suominen 1979; Bailey and Wisskirchen 2006) and country scale, the latter also addressing the rates of species expansion (Conolly 1977; Mandák et al. 2004). As a result, an increase in data resolution with decreasing spatial extent was achieved (Collingham et al. 2000). Further studies attempted to identify invaded habitats in the British Isles (Beerling 1991; Beerling et al. 1994; Bailey et al. 1996; Child and de Waal 1997; Hathaway 2000), the Czech Republic (Pyšek and Prach 1993; Mandák et al. 2004), and France (Jager 1994; Boyer 2002; Voinot et al. 2002), but these analyses were largely descriptive. Few studies have evaluated habitat selection at a landscape scale by invasive Fallopia species (see for example (Bímová et al. 2004)) or the dynamics of habitat patch colonization by invasive Fallopia and the hybrid F. × bohemica.

The focus of our study was to analyse the distribution and dynamics of four alien invasive Fallopia taxa at a landscape scale with the aim to test two specific hypotheses: (1) Fallopia taxa preferentially colonize humandisturbed habitats; (2) Sexual reproduction plays a significant role in Fallopia population dynamics resulting in a higher rate of colonization in $F . \times$ bohemica compared to its progenitor species. Therefore, we addressed the following questions: (1) which habitats were most often selected by the target species in Belgium? (2) At a landscape scale, was the dynamics of colonization of new habitat patches different from the dynamics of spread within habitat patches? and (3) Does the hybrid $F . \times$ bohemica differ in its habitat selection invasion dynamics at the landscape scale relative to the parental species $F$. japonica and $F$. sachalinensis?

\section{MATERIALS AND METHODS}

\section{Study area and population survey}

This study was conducted on the upper basin of the Orneau River in Gembloux, Belgium (50³3' N; 441' E). The locality is a semi-rural landscape of 1,118 ha comprised of agricultural and urban land. We performed a complete landscape survey in September/October 2001, 2002 and 2003 to locate all individuals of F. japonica, $F$. sachalinensis, $F$. $\times$ bohemica and $F$. aubertii using a 1/10,000 topographical map (National Geographical 
Institute, Belgium). Due to the high clonality of Fallopia spp., distinguishing ramet from genet within a habitat patch was difficult. Our approach was to identify the dynamics of focal points; therefore we arbitrarily determined that two ramets or groups of ramets separated by more than $1 \mathrm{~m}$ represented two different individuals. We acknowledge that different ramets may belong to the same clone. However, our study was designed to serve the following two purposes: (1) distinguish between intra-patch dynamics, likely the result of clone extension; and (2) inter-patch dynamics, presumably the result of new clone settlement, whether by vegetative propagation or seed dispersion. Location, taxonomic status, maximum and minimum diameter of each individual were recorded in the field. The area covered by each individual was estimated from its two longest axes. Data were transferred into a land use cover map Top10v-GIS (National Geographical Institute, Belgium) using Arcview (version 3.2, Environmental Systems Research Institute Inc.).

\section{Habitat assessment}

The landscape structure (habitat type and spatial configuration) was characterized on the basis of recent land use cover maps (IGN TOP10V-GIS). The TOP10V-GIS database provided different levels of resolution depending on the habitat type. For example, detailed localisation of some building types compared to a general class for cultivated land. We subsequently grouped the different land use types into more general classes with a similar level of resolution, including natural/semi-natural forest (broad-leaved forests with woody undergrowth and mixed forests with broad-leaved trees and conifers), exotic plantation (poplar plantations and coniferous forests), lawn, meadow, orchard, farming, ruderals (ruderal and ruderal scrubby vegetation, brushwood and waste places), urban non-industrial (intensive human use with much of the land covered by buildings such as schools, pleasure gardens, cemeteries and churches), urban industrial (in use and abandoned commercial and industrial buildings, shelters, silos, plant nurseries, greenhouses, and water catchments), marshland, stagnant water, running water, roads, and railways. For convenience, rivers, roads, and railways were referred to collectively as communication routes.

\section{Habitat selection}

Habitat selection was assessed each year independently for each taxon using the selection index $B \operatorname{surf}_{i}=$ $\left[\left(n_{i} / N\right) /\left(S_{i} / S\right)\right]$ (Manly et al. 1993); where $n_{i}$ is the surface area occupied by all individuals of each taxon in the $i$ th habitat, $N$ the surface area occupied by all individuals of each taxon, $S_{i}$ the surface area occupied by the $i$ th habitat and, $S$ the total surface area of the delimited landscape. We used surface area instead of the number of individuals because the latter may be a biased estimate of the species importance in a given habitat due to the characteristic clonality of Fallopia. If habitat use is random, the expected $B_{i}$ value will be 1.0 for each habitat type. Significant departures from 1.0 indicate that habitat use is selective. We employed $\chi^{2}$ analyses to determine if specific habitat types are used more or less than would be expected under random individual distributions. Comparisons of the use of each habitat type to its availability were performed. Analyses were executed using Mini-tab 2006 (version 15.1.0.0, Minitab Inc.). Population size for both $F$. sachalinensis (one individual) and $F$. aubertii (three individuals) was too low to estimate selection indices, so neither taxon was used in statistical analyses.

Preliminary analyses indicated that individuals of Fallopia were often distributed at the edge of habitat patches. The conditions at the ecotone are often different from those in the core habitat, therefore each year we also assessed habitat selection along the margins of habitat types for both $F$. japonica and $F$. $\times$ bohemica using the following selection index:

Bedge $_{i}=\left[\left(n_{i} / N\right) /\left(P_{i} / P\right)\right]$, where $P_{i}$ represents the perimeter of the $i$ th habitat, and $P$ the perimeter of all habitat patches within the landscape unit.

In addition, we evaluated Fallopia japonica and $F . \times$ bohemica distribution along the border of communication routes. Five-meter and 10-m buffers were delimited along railways, roads, and rivers, and the percent of individuals distributed within these buffers was recorded on a yearly basis.

\section{Dynamics of Fallopia populations}

The global dynamics of Fallopia spread was estimated by determining individual density per square kilometre for each species and the rate of increase each year was calculated as (density of individuals $\left.\mathrm{year}_{x}\right) /($ density of individuals $\left.\mathrm{year} x-1_{1}\right) \times 100$. The emergence rate of new individuals was determined as the ratio of $\left(\right.$ new individuals year $\left.x_{x}\right) /\left(\right.$ individuals $\left._{\text {year } x-1}\right) \times 100$ and the extinction rate for each species was estimated by the ratio $\left(\right.$ extinct individuals $\left._{\text {year } x}\right) /\left(\right.$ individuals year $\left.x-1_{1}\right) \times 100$. The dynamics of new patch colonization compared to 
propagation within occupied patches was evaluated by addressing patch colonization dynamics for each of the different taxa by recording the number of unoccupied patches on year ${ }_{n-1}$ that was colonized on year ${ }_{n}$.

To characterize Fallopia propagation along linear landscape elements, we followed Fallopia growth dynamics along a $3 \mathrm{~km}$ segment of a busy road connecting Gembloux to Louvain-la-Neuve (Nationale 4, 5040' N; $4^{\circ} 37^{\prime}$ E). Each individual was located and its length measured at four time periods: September 2001, May 2002, July 2003 and August 2003 using a decametre (Stabila, Germany). The growth of each individual was assessed as the ratio of (observed length for a given period-length of the previous period)/length of the previous period.

The mean size differences (surface area or length) of individuals of $F$. japonica and $F$. $\times$ bohemica between the different periods were compared for each taxon using paired $t$-tests performed with Statistica (version 7.1, Statsoft Inc. 2005)

\section{RESULTS}

\section{Habitat selection}

The landscape was composed of 2,175 habitat patches with a mean size \pm s.d. $=79.8 \pm 172.1$ ha. The study area was dominated by farming (crops) and urban/ruderal land uses (Fig. 1). Extensive meadows were also represented and constituted an important habitat type. During the study period, significant changes in the landscape structure were not observed but disturbances such as new building developments and soil displacement were recorded.

Three individuals of Fallopia aubertii were recorded on boundary walls in urban non-industrial land and a single F. sachalinensis individual was found near a greenhouse also in urban non-industrial land. For both taxa, no additional individuals were documented during the study. Consequently, habitat selection and dynamics were not further considered for the two species. Ruderal habitats were preferred by both $F$. japonica and $F$. $\times$ bohemica, with selection indices ranging from 13.0 to 13.1 and selection indices of 2.5-2.6 for natural/ semi-natural forests. In all cases, selection indices differed significantly from 1.0 (Table 1). A significant selection index was indicated for urban non-industrial habitats in $F$. $\times$ bohemica but not $F$. japonica. All other habitats were either not colonized by the two species or the proportion of occupation was not significantly different from expectations under random colonization.

Fig. 1 Landscape composition on the upper basin of the Orneau River in Gembloux, Belgium, 2001-2003

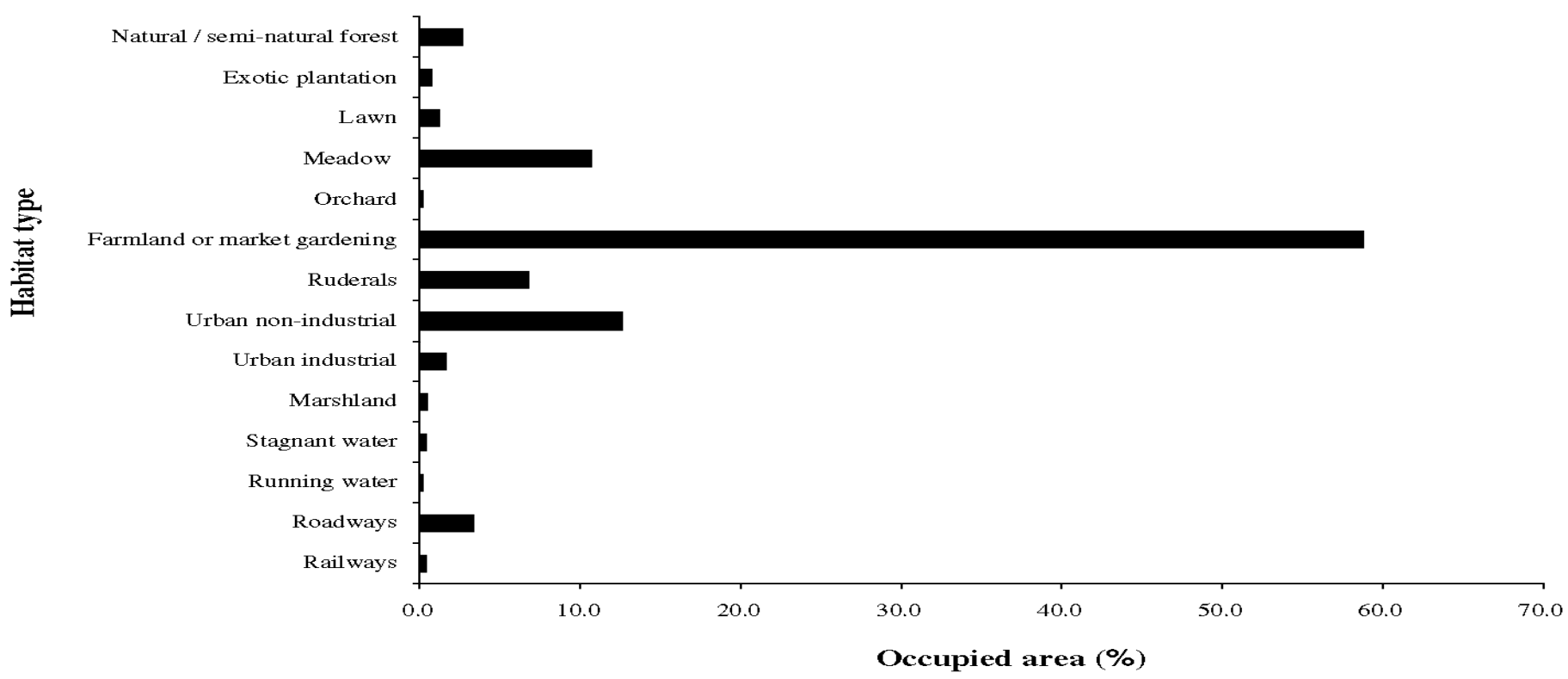


Table 1 Selection indices (Bsurf $)_{i}$ ) for Fallopia japonica and Fallopia $x$ bohemica in different habitat types on the upper basin of the Orneau River in Gembloux, Belgium, 2001-2003

\begin{tabular}{|c|c|c|c|c|c|c|c|c|c|}
\hline \multirow[t]{2}{*}{ Habitat type } & \multicolumn{3}{|c|}{ Both Fallopia populations } & \multicolumn{3}{|c|}{ Fallopia japonica } & \multicolumn{3}{|c|}{ Fallopia $\times$ bohemica } \\
\hline & 2001 & 2002 & 2003 & 2001 & 2002 & 2003 & 2001 & 2002 & 2003 \\
\hline Natural/semi-natural forest & $2.6^{*}$ & $2.5^{*}$ & $2.5^{*}$ & $2.7 *$ & $2.6^{*}$ & $2.6^{*}$ & $2.4^{*}$ & $2.3^{*}$ & $2.3^{*}$ \\
\hline Exotic plantation & 0.0 & 0.0 & 0.0 & 0.0 & 0.0 & 0.0 & 0.0 & 0.0 & 0.0 \\
\hline Lawn & 0.0 & 0.0 & 0.0 & 0.0 & 0.0 & 0.0 & 0.0 & 0.0 & 0.0 \\
\hline Meadow & 0.0 & 0.0 & 0.0 & 0.0 & 0.0 & 0.0 & 0.0 & 0.0 & 0.0 \\
\hline Orchard & 0.0 & 0.0 & 0.0 & 0.0 & 0.0 & 0.0 & 0.0 & 0.0 & 0.0 \\
\hline Farming & 0.0 & 0.0 & 0.0 & 0.0 & 0.0 & 0.0 & 0.0 & 0.0 & 0.0 \\
\hline Ruderals & $13.0 *$ & $13.1 *$ & $13.1 *$ & $13.4^{*}$ & $13.5^{*}$ & $13.5^{*}$ & $11.6 *$ & $11.7 *$ & $11.7 *$ \\
\hline Urban non-industrial & 0.4 & 0.4 & 0.4 & 0.1 & 0.2 & 0.2 & $1.2 *$ & $1.1^{*}$ & $1.1 *$ \\
\hline Urban industrial & 0.0 & 0.0 & 0.0 & 0.0 & 0.0 & 0.0 & 0.0 & 0.0 & 0.0 \\
\hline Marshland & 0.0 & 0.0 & 0.0 & 0.0 & 0.0 & 0.0 & 0.0 & 0.0 & 0.0 \\
\hline Stagnant water & 0.0 & 0.0 & 0.0 & 0.0 & 0.0 & 0.0 & 0.0 & 0.0 & 0.0 \\
\hline Running water & 0.0 & 0.0 & 0.0 & 0.0 & 0.0 & 0.0 & 0.0 & 0.0 & 0.0 \\
\hline Roadways & 0.0 & 0.0 & 0.0 & 0.0 & 0.0 & 0.0 & 0.0 & 0.0 & 0.0 \\
\hline Railways & 0.0 & 0.0 & 0.0 & 0.0 & 0.0 & 0.0 & 0.0 & 0.0 & 0.0 \\
\hline
\end{tabular}

Habitats exploited more than expected under random distributions are marked with a asterisk $(P<0.001)$. For details see the text

Seventy percent of Fallopia japonica and $100 \%$ of $F . \times$ bohemica populations were situated along habitat patch borders. Railway borders, running water, and marshland were selected by $F$. japonica and $F$. $\times$ bohemica more than expected (Table 2). In all cases, the selection index differed significantly from 1.0. Roadsides and the edge of stagnant water, urban industrial and farmland habitats were favoured by $F$. japonica but not by $F$. $\times$ bohemica. Fallopia $\times$ bohemica exceeded expectations for colonization of meadow margins, exotic plantations, and natural/semi-natural forests edges. Other habitat borders were not selected by either species.

On average, over the 3-year study period, $71 \%$ of all Fallopia individuals occurred within a 10-m buffer around total linear networks (roads, railways, and rivers) and 59\% within a 5-m buffer. However, these buffers represented only $14.5 \%$ and $7.9 \%$ of the total landscape surface, respectively (Fig. 2). More than half of the individuals were situated along roads.

Table 2 Selection indices $\left(\right.$ Bedge $\left._{i}\right)$ for Fallopia japonica and Fallopia $\times$ bohemica along different habitat type borders on the upper basin of the Orneau River in Gembloux, Belgium, 2001-2003

\begin{tabular}{lccccccccc}
\hline Habitat type & \multicolumn{3}{c}{ Both Fallopia populations } & Fallopia japonica & \multicolumn{3}{c}{ Fallopia $\mathrm{x}$ bohemica } \\
\cline { 2 - 9 } & 2001 & 2002 & 2003 & 2001 & 2002 & 2003 & 2001 & 2002 & 2003 \\
\hline Natural/semi-natural forest & 0.5 & 0.5 & 0.5 & 0.0 & 0.0 & 0.0 & $2.3^{*}$ & $2.3^{*}$ & $2.3^{*}$ \\
Exotic plantation & $3.4^{*}$ & $3.3^{*}$ & $3.3^{*}$ & 0.9 & 0.9 & 0.9 & $12.5^{*}$ & $12.4^{*}$ & $12.4^{*}$ \\
Lawn & 0.0 & 0.0 & 0.0 & 0.0 & 0.0 & 0.0 & 0.0 & 0.0 & 0.0 \\
Meadow & 0.7 & 0.6 & 0.6 & 0.0 & 0.0 & 0.0 & $3.1^{*}$ & $3.1^{*}$ & $3.1^{*}$ \\
Orchard & 0.0 & 0.0 & 0.0 & 0.0 & 0.0 & 0.0 & 0.0 & 0.0 & 0.0 \\
Farming & $1.0^{*}$ & $1.2^{*}$ & $1.2^{*}$ & $1.3^{*}$ & $1.6^{*}$ & $1.6^{*}$ & 0.0 & 0.0 & 0.0 \\
Ruderals & 0.0 & 0.0 & 0.0 & 0.0 & 0.0 & 0.0 & 0.0 & 0.0 & 0.0 \\
Urban non-industrial & 0.2 & 0.1 & 0.1 & 0.2 & 0.2 & 0.2 & 0.0 & 0.0 & 0.0 \\
Urban industrial & $1.3^{*}$ & $1.3^{*}$ & $1.3^{*}$ & $1.7^{*}$ & $1.6^{*}$ & $1.6^{*}$ & 0.0 & 0.0 & 0.0 \\
Marshland & $10.1^{*}$ & $9.8^{*}$ & $9.9^{*}$ & $10.2^{*}$ & $9.8^{*}$ & $9.9^{*}$ & $9.8^{*}$ & $9.7^{*}$ & $9.7^{*}$ \\
Stagnant water & $1.5^{*}$ & $1.4^{*}$ & $1.4^{*}$ & $1.8^{*}$ & $1.7^{*}$ & $1.7^{*}$ & 0.4 & 0.4 & 0.4 \\
Running water & $6.7^{*}$ & $6.6^{*}$ & $6.6^{*}$ & $4.7^{*}$ & $4.7^{*}$ & $4.7^{*}$ & $14.1^{*}$ & $13.9^{*}$ & $13.9^{*}$ \\
Roadways & $1.1^{*}$ & $1.2^{*}$ & $1.2^{*}$ & $1.1^{*}$ & $1.2^{*}$ & $1.2^{*}$ & 1.2 & 1.2 & 1.2 \\
Railways & $5.3^{*}$ & $5.2^{*}$ & $5.2^{*}$ & $7.0^{*}$ & $6.0^{*}$ & $6.1^{*}$ & $2.0^{*}$ & $1.8^{*}$ & $1.8^{*}$ \\
\hline
\end{tabular}

Habitats exploited more than expected under random distributions are marked with a asterisk $(P<0.001)$. For details see the text 
Fig. 2 Percent Fallopia individuals averaged over 3 years, within 5 and 10-m buffers around rivers, roads and railways on the upper basin of the Orneau River in Gembloux, Belgium, 2001-2003. Percent area covered by these linear networks in the landscape is also depicted

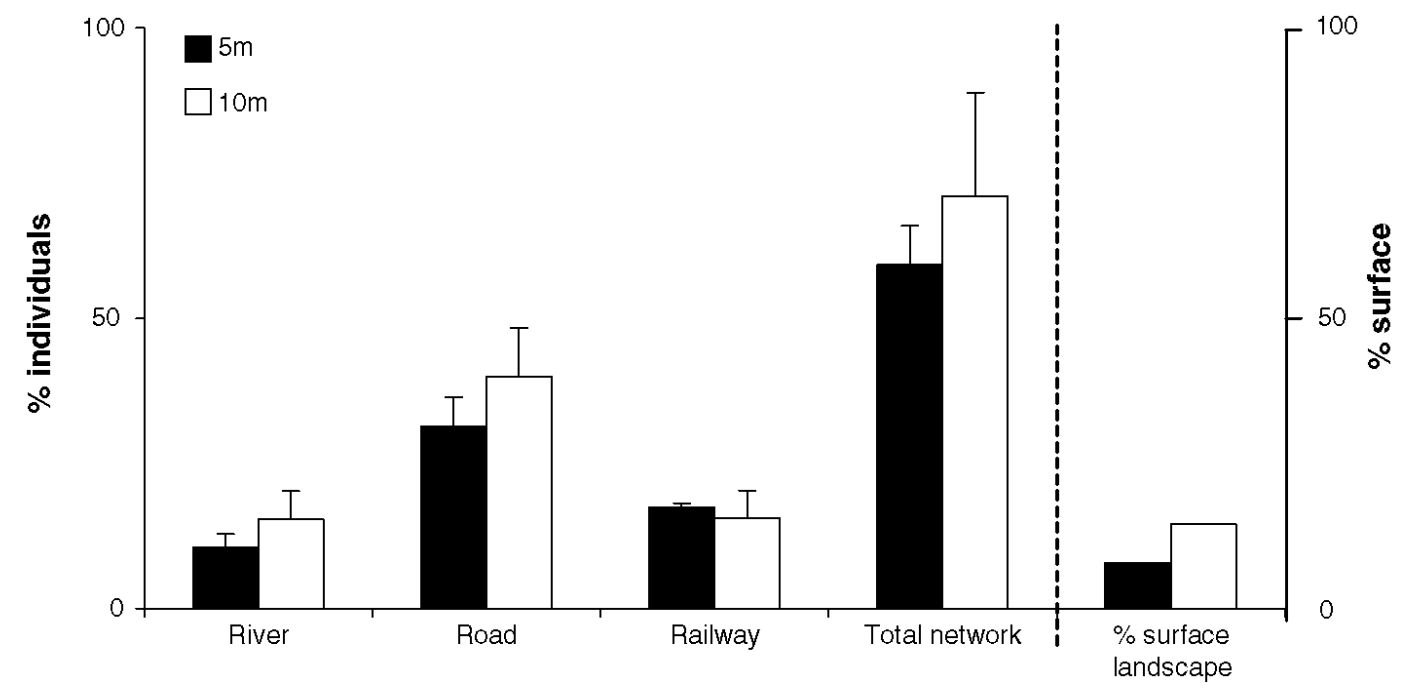

\section{Fallopia population dynamics}

A total of 77 Fallopia individuals were present in the study area at the onset of the study. Fallopia japonica was the most widespread species ( $80.5 \%$ of all individuals, density 5.5 individuals $/ \mathrm{km}^{2}$ ) (Table 3). Fallopia $\times$ bohemica was less widespread (14.3\% of all individuals, density 1.0 individual $/ \mathrm{km}^{2}$ ). The global spread dynamics Fallopia was high but varied between years (rate of increase $68.1 \%$ and $26.7 \%$ in 2002 and 2003, respectively). The difference resulted from lower emergence rates in 2003 compared to 2002, but in both years emergence rates far exceeded mortality rates (Table 3 ). The high rate of numerous small individual increases in already colonized patches was in the vicinity of mature plants, and likely the result of vegetative (clonal) reproduction. For both years, the rate of increase in individual numbers was higher for $F$. japonica $(75.8 \%$ and $35.2 \%$, in 2002 and 2003, respectively) than for $F$. $\times$ bohemica (63.6\% and $0 \%$ in 2002 and 2003 respectively). The total landscape surface area occupied by Fallopia individuals (represented by $F$. japonica and $F$. $\times$ bohemica) increased by $34.7 \%$, with comparable area growth increases for $F$. japonica and $F$. $\times$ bohemica $\left(34.9 \%\right.$ and $34.7 \%$, respectively). As much as $39.6 \%$ of the individuals covered surfaces greater than $10 \mathrm{~m}^{2}$, and $24.4 \%$ of that number occupied more than $100 \mathrm{~m}^{2}$. Individual mean surface area decreased over years, but it was due to the emergence of numerous small individuals $\left(<1 \mathrm{~m}^{2}\right)$. Significant increases in mean size were detected for $F$. $\times$ bohemica in 2001-2002 (paired $t$-test; $\mathrm{dl}=10 ; t=-4.306 ; P=0.001$ ) but not in 2002-2003 (paired $t$-test; $\mathrm{dl}=10 ; t=-2.029 ; P=0.070)$. Significant mean size increases were found in $F$. japonica between 2001 and 2002 (paired $t$-test; $\mathrm{dl}=57 ; t=-3,293 ; P=0.002$ ) and 2002-2003 (paired $t$-test; $\mathrm{dl}=57 ; t=-3.293 ; P=0.002$ ).

In contrast to within patch dynamics, the rate of new patch habitat colonization was low. In 2001, Fallopia japonica and $F . \times$ bohemica were documented in 38 and 9 habitat patches, respectively (Table 4). In 2002, we recorded a new habitat colonization rate of $4.3 \%$ with two habitat patches settled by $F$. japonica (one farmland and one urban non-industrial) and one by $F . \times$ bohemica (one ruderal habitat). In 2003, this rate decreased to $2.1 \%$ with three habitat patches colonized by $F$. japonica (two ruderal and one natural/semi-natural forest). The minimal distance between newly colonized and patch occupied the previous year was $10 \mathrm{~m}$ and the maximum distance was $105 \mathrm{~m}$.

The growth dynamics analysis identified 31 individuals of Fallopia japonica covering $2.3 \%$ of the study length along the road connecting Gembloux to Louvain-la-Neuve (Nationale 4) in September 2001. The mean length of individuals was $4.0 \pm 4.1 \mathrm{~m}$ (mean \pm s.d.), ranging from 0.1 to $15.0 \mathrm{~m}$. In May 2002, July 2003, and August 2003 the mean length of individuals increased by $20.1 \pm 31.4 \%, 73.8 \pm 256.7 \%$, and $93.8 \pm 272.1 \%$, respectively. Three newly established individuals were observed (two in July 2003 and one in August 2003) and two stands merged in July 2003. The two new individuals reported in July 2003 were $3 \mathrm{~m}$ from the nearest established stand, and the individual documented in August 2003 was approximately $15 \mathrm{~m}$ from its nearest neighbour. Mortality was not observed within any of the patches. 


\section{DISCUSSION}

Habitat selection in Fallopia japonica and $F . \times$ bohemica was examined employing two complementary approaches: patch scale and patch edge analyses. We used this methodology because a large proportion of $F$. japonica and $F . \times$ bohemica individuals were distributed at the edge of habitat patches where conditions might be different than in the patch core. The two approaches provided different but complementary data on habitat selection.

Regardless of the approach, Fallopia japonica and $F . \times$ bohemica exhibited a similar pattern of habitat selection. Results of the patch analysis were consistent with our hypothesis that Fallopia spp. preferentially colonized disturbed areas, with ruderal habitats most often selected. However, high levels of disturbance seemed to hamper species colonization. Farmland where crop cultivation practices result in yearly soil and vegetation disturbance did not support the species. High levels of perturbation may preclude the establishment of these perennial taxa, but the potential role of herbicide application cannot be excluded. Results drawn from the edge analysis indicated the importance of aquatic and humid habitats in the species distribution patterns. When present, edges of these habitats were favoured.

Analysis of Fallopia japonica and F. $\times$ bohemica distribution along linear networks showed that in 2001, the majority of individuals $(91.0 \%)$ occurred within a 10-m buffer along communication routes, which promoted the likelihood of dispersion and expansion to adjacent habitat patches. Growth assessment along the main road between Gembloux and Louvain-La-Neuve (Nationale 4) indicated high rates of individual size growth. Our results point to the importance of linear landscape structure in the invasion dynamics of Fallopia taxa. However, we did not test for a potential relationship between linear networks, especially roads, and habitat types. As a result, we could not determine whether habitat selection and road networks were independent. Ruderal habitats may be associated with roads more than others, supporting the increased frequency of $F$. japonica and $F$. $\times$ bohemica in this habitat type. However, we have no data to support this inference and it is therefore only speculative.

Examination of species dynamics at the landscape scale did not support two of our hypotheses. The importance of sexual reproduction in the invasion dynamics of Fallopia and any further advantage of $F$. $\times$ bohemica due to both vegetative and sexual reproduction was not supported. In the study landscape, the species spread dynamics was high within colonized patches while new patch colonization was low. Extension within patches was most likely due to clonality for two reasons. First data suggested all new individuals were not derived from seeds due to their increased height. Second new $F$. $\times$ bohemica did not establish in close vicinity to $F$. japonica. This would be the case if seedling emergence was the cause of spread, because all seeds generated by $F$. japonica are hybrids issued from direct crosses with $F$. sachalinensis or back cross with $F . \times$ bohemica (Tiébré et al. 2007b). The high potential for vegetative reproduction has long been considered responsible for the spread dynamics of Fallopia taxa in their introduced range (Bímová et al. 2003; Mandák et al. 2004), but this view has recently been challenged on the North American continent where hybridization is more common than on the European continent (Gammon et al. 2007; Grimsby et al. 2007). The high rate of spread was also caused by low extinction rates. Pyšek et al. (2001) demonstrated that some Fallopia persisted for more than a century at the same site. 


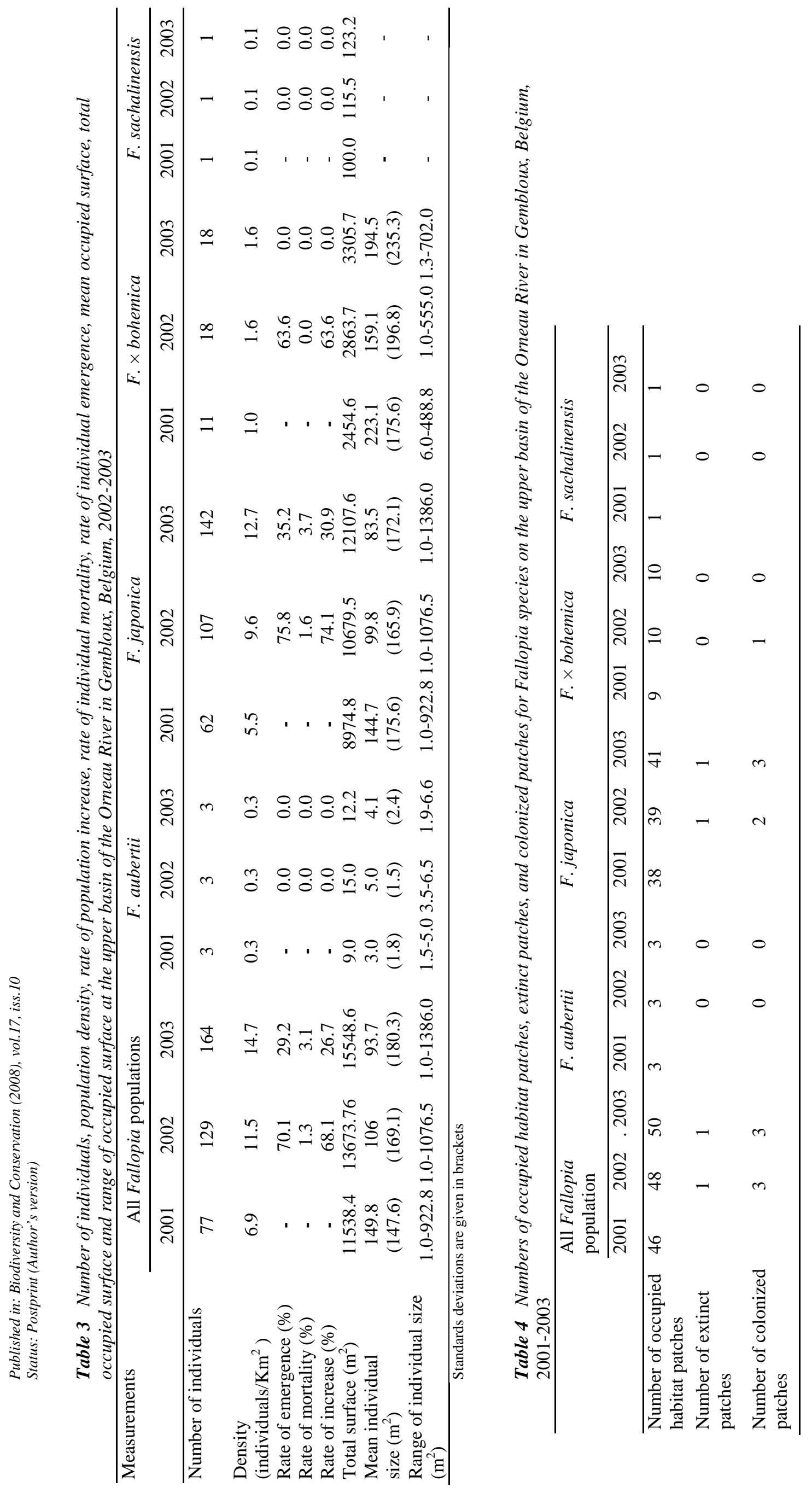


Previous studies in Belgium have demonstrated sexual reproduction in Fallopia japon-ica, despite its malesterility. Clones produced numerous viable hybrid seeds originating from crosses with other parental Fallopia species or backcrosses with $F$. $\times$ bohemica (Tiébré et al. 2007a). High genetic variability in $F . \times$ bohemica suggested most adult hybrids observed in Belgium originated from sexual reproduction (Tiébré et al. 2007b). Propagule pressure at the landscape scale may be high and $F$. japonica clones produced on average 2,000 seeds $/ \mathrm{m}^{2}$ (Tiébré et al. 2007a). The surface colonized by $F$. japonica could result in seed dispersal over the landscape of approximately $14 \times 10^{6}$ seeds. Wind-dispersed seeds were found in close vicinity to the parents, but dispersal over habitat patch limits has been shown to be possible, albeit at low frequency (Tiébré et al. 2007a). High potential for hybrid seed production was reported, but led to a puzzling observation from the present study. The landscape survey did not indicate increased establishment dynamics for $F$. $\times$ bohemica plants compared to $F$. japonica. This suggested that conditions for seedling establishment might be restrictive. Nevertheless, only a small proportion of seeds are needed to develop and subsequently enhance the regeneration potential of the Fallopia species complex. A low proportion of seedling establishment even under substantial seed production is common in plants. Our results were incongruent with Pyšek et al. (2003) who showed increased invasive dynamics of $F . \times$ bohemica in the Czech Republic. Pyšek et al. (2003) argued that its higher invasive potential was due to a combination of sexual and vegetative reproduction, higher vegetative growth, and genotypic diversity of the hybrids. The differences in the two studies were likely the result of different spatial and temporal scales, and differences in methodology. The Czech study was based on herbarium specimen data and our study entailed direct field surveys. Low seedling establishment may be due to selection against unbalanced hybrids, effects of winter on seed viability, competition with native vegetation, and predation (Tiébré et al. 2007a).

\section{CONCLUSIONS}

Worldwide reduction in biodiversity warrants the rapid establishment of management priorities for invasive species control and habitat protection. In this study, we explored habitat selection and distribution dynamics of four invasive alien clonal plants in the genus Fallopia. Disturbed sites demonstrated enhanced recruitment, colonization and spread of Fallopia species. Given an assumption of habitat destruction, fragmentation, and short-term disturbance, disturbed habitats play the most important role in the distribution of alien invasive Fallopia. Our results point to management of disturbed habitats and ecosystems to prevent invasion by exotic alien species and the subsequent maintenance of native ecosystems. In addition, the preferential location of Fallopia individuals along communication networks demonstrated that efforts to control invasion may focus on priority towards a limited proportion of the landscape and should target specific actors involved in those network management.

\section{Acknowledgements}

We thank Béatrice Lagrange for field assistance, John P. Bailey for improving our English and an anonymous reviewer for helpful suggestions. Marie-S. Tiébré was funded by the Ministry of Education and Scientific Research of the Republic of Ivory Coast. This research was supported by the Belgian Science Policy project "INPLANBEL: Invasive Plants in Belgium: Patterns, Processes and Monitoring" (contract EV/11/27C) and by the F.R.S.-FNRS (contract FRFC 2.4556.05).

\section{References}

Adriaens T, Gomez GMS, Maes D (2008) Invasion history, habitat preferences and phenology of the invasive ladybird Harmonia axyridis in Belgium. Biocontrol 53:69-88. doi: 10.1007/s10526-007-9137-6

Bailey JP (2003) New records for Fallopia $\times$ conollyana: is it truly such a rarity? Watsonia 24:451-453

Bailey JP, Stace CA (1992) Chromosome number, morphology, pairing, and DNA values of species and hybrids in the genus Fallopia (Polygonaceae). Plant Syst Evol 180:29-52. doi:10.1007/BF00940396

Bailey JP, Wisskirchen R (2006) The distribution and origins of Fallopia $\times$ bohemica (Polygonaceae) in Europe. Nord J Bot 24:173-199

Bailey JP, Child L, Conolly AP (1996) A survey of the distribution of Fallopia x Bohemica (Chrtek \& Chrtkova J. Bailey (Polygonaceae) in the British Isles. Watsonia 21:187-198 
Published in: Biodiversity and Conservation (2008), vol.17, iss.10

Status: Postprint (Author's version)

Beerling DJ, Bailey JP, Conolly AP (1994) Biological flora of the British Isles. Fallopia japonica (Houtt.) Ronse Decraene. J Ecol 82:959979. doi: $10.2307 / 2261459$

Bímová KBE, Mandák BBC, Pyšek P (2003) Experimental study of vegetative regeneration in four invasive Reynoutria taxa (Polygonaceae). Plant Ecol 166:1-11. doi:10.1023/A:1023299101998

Bímová K, Mandák B, Kašparov I (2004) How does Reynoutria invasion fit the various theories of invasibility. J Veg Sci 15:495-504. doi:10.1658/1100-9233(2004)015[0495:HDRIFT]2.0.CO;2

Boyer M (2002) Cartographie des renouées du Japon sur le réseau hydrographique du bassin Rhone-Méditerranée-Corse (Hors SaoneDoubs). In: Journées techniques nationales "renouées". Association Echel, Besançon, France

Buse A (1988) Habitat selection and grouping of beetles (Coleoptera). Holarctic Ecol 11:241-247

Child L, de Waal L (1997) The use of GIS in the management of Fallopia japonica in the urban environment. In: Brock JH, Wade M, Pyšek P, Greene DF (eds) Plant invasions: studies from North America and Europe. Backhuys Publishers, Leiden, The Netherlands, pp 207-220

Child L, Wade M (2000) The Japanese knotweed manual. Packard Publishing Limited, Chichester, West Sussex

Christen D, Matlack G (2006) The role of roadsides in plant invasions: a demographic approach. Conserv Biol 20:385-391. doi:10.1111/j.1523-1739.2006.00315.x

Cock MJW (1978) The assessment of preference. J Anim Ecol 47:805-816. doi: 10.2307/3672

Collingham YC, Wadsworth RA, Huntley B, Hulme PE (2000) Predicting the spatial distribution of non-indigenous riparian weeds: issues of spatial scale and extent. J Appl Ecol 37(Suppl 1): 13-27. doi: 10.1046/j.1365-2664.2000.00556.x

Conolly AP (1977) The distribution and history in the British Isles of some alien species of Polygonum and Reynoutria. Watsonia 11:291311

Duriez O, Ferrand Y, Binet F, Corda E, Gossmann F, Fritz H (2005) Habitat selection of the Eurasian woodcock in winter in relation to earthworms availability. Biol Conserv 122:479-190. doi:10.1016/j.biocon.2004.08.011

Forman RTT, Alexander LE (1998) Roads and their major ecological effects. Annu Rev Ecol Syst 29:207- 231. doi: 10.1146/annurev.ecolsys.29.1.207 Fox MD,

Fox BJ (1986) The susceptibility of natural communities to invasion. In: Groves RH, Burdon JJ (eds) Ecology of biological invasions. Cambridge University Press, New York, pp 57-66

Gammon MA, Grimsby JL, Tsirelson D, Kesseli RV (2007) Molecular and morphological evidence reveals introgression in swarms of the invasive taxa Fallopia japonica, F. sachalinensis, and F. x bohemica (Polygonaceae) in the United States. Am J Bot 94:948-956. doi:10.3732/ajb.94.6.948

Godefroid S (1996) A propos de l'extension spectaculaire de Fallopia japonica, F. sachalinensis, Buddleja davidii et Senecio inaequidens en région bruxelloise. Dumotiera 63:9-16

Grimsby JL, Tsirelson D, Gammon MA, Kesseli RV (2007) Genetic diversity and clonal vs. sexual reproduction in Fallopia spp. (Polygonaceae). Am J Bot 94:957-964. doi:10.3732/ajb.94.6.957

Hathaway S (2000) Surveys on the spread of Japanese knotweed Fallopia japonica in Swansea and strategies for its control. Asp Appl Biol 28:55-62

Hobbs RJ, Humphries SE (1995) An integrated approach to the ecology and management of plant invasions.Conserv Biol 9:761-770. doi:10.1046/j.1523-1739.1995.09040761.x

Huang H, Zhang L (2007) A study of the population dynamics of Spartina alterniflora at Jiuduansha shoals, Shanghai, China. EcolEng 29:164-172. doi:10.1016/j.ecoleng.2006.06.005

Jager C (1994) Repartition, écologie et possibilités de contrôle de l' expansion de la renouée du Japon en Lorraine. Mémoire de Maitrise. Universite de Metz, Metz

Jalas J, Suominen J (1979) Atlas florae europaeae. 4. Polygonaceae. Societas Vanamo, Helsinki, Finland

Kamler IF, Gipson PS (2000) Space and habitat use by resident and transient coyotes. Can J Zool 78:2106-2111.doi:10.1139/cjz-78-12-2106

Lonsdale WM (1999) Global patterns of plant invasions and the concept of invasibility. Ecology 80:1522-1536

Mandák BBC, Pyšek P, Bímová KBE (2004) History of the invasion and distribution of Reynoutria taxa in the Czech Republic: a hybrid 
Published in: Biodiversity and Conservation (2008), vol.17, iss.10

Status: Postprint (Author's version)

spreading faster than its parents. Preslia, Praha 76:15-64

Manly BFJ, McDonald LL, Thomas DL (1993) Resource selection by animals: statistical design and analysis for field studies. Chapman and Hall, London

Martinez J-J, Wool D (2006) Sampling bias in roadsides: the case of galling aphids in Pistacia trees. Biodiv-ers Conserv 15:2109-2121. doi:10.1007/s10531-004-6685-2

Marvier M, Kareiva P, Neubert MG (2004) Habitat destruction, fragmentation, and disturbance promote invasion by habitat generalists in a multispecies metapopulation. Risk Anal 24:869-878. doi:10.1111/ j.0272-4332.2004.00485.x

Panetta FD, Hopkins AJ (1991) Weeds in corridors: invasion and management. In: Saunders DA, Hobbs RJ (eds) Nature conservation 2: the role of corridors. Surrey Beatty and Sons, London, pp 341-351

Parendes LA, Jones JA (2000) Role of light availability and dispersal in exotic plant invasion along roads and streams in the H. J. Andrews experimental forest, Oregon. Conserv Biol 14:64-75. doi:10.1046/j.1523-1739.2000.99089.x

Pashley CH, Bailey IP, Ferris C (2007) Clonal diversity in British populations of the alien invasive giant knot-weed, Fallopia sachalinensis (F. Schmidt) Ronse Decraene, in the context of European and Japanese plants. Watsonia 26:359-371

Perrins J, Fitter A, Williamson M (1993) Population biology and rates of invasion of three introduced Impa-tiens species in the British Isles. J Biogeogr 20:33-44. doi: 10.2307/2845737

Pyšek P, Prach K (1993) Plant invasions and the role of riparian habitats: a comparison of four species alien to central Europe. J Biogeogr 20:413-420. doi: 10.2307/2845589

Pyšek P, Richardson DM (2006) The biogeography of naturalization in alien plants. J Biogeogr 33:2040-2050. doi:10.1111/j.13652699.2006.01578.x

Pyšek P, Mandák B, Francirkova T, Prach K (2001) Persistence of stout clonal herbs as invaders in the landscape: a field test of historical records. In: Brundu G, Brock I, Camarda I, Child L, Wade M (eds) Plant invasions: species ecology and ecosystem management. Backhuys, Leiden, Netherlands, pp 235-244

Pyšek P, Brock JH, Bímová K, Mandák B, Jarosík V, Koukolíková I, Pergl J, Stepánek J (2003) Vegetative regeneration in invasive Reynoutria (Polygonaceae) taxa: the determinant of invasibility at the genotype level. Am J Bot 90:1487-1495

Richardson DM, Holmes PM, Esler KJ, Galatowitsch SM, Stromberg JC, Kirkman SP, Pyšek P, Hobbs RJ (2007) Riparian vegetation: degradation, alien plant invasions, and restoration prospects. Divers Distrib 13:126-139

Saintenoy-Simon J (2003) Les plantes exotiques naturalisées et les espèces invasives de Wallonie. Parcs et Réserves 58:23-39

Song IJ, Hong SK, Kim HO, Byun B, Gin Y (2005) The pattern of landscape patches and invasion of naturalized plants in developed areas of urban Seoul. Landsc Urban Plan 70:205-219. doi:10.1016/j.land-urbplan.2003.10.018

Tiébré M-S, Bizoux J-P, Hardy OJ, Bailey JP, Mahy G (2007a) Hybridization and morphogenetic variation in the invasive alien Fallopia (Polygonaceae) complex in Belgium (Western Europe). Am J Bot 94:1900-1910. doi:10.3732/ajb.94.11.1900

Tiébré M-S, Vanderhoeven S, Saad L, Mahy G (2007b) Hybridization and sexual reproduction in the invasive alien Fallopia (Polygonaceae) complex in Belgium. Ann Bot 99:193-203. doi:10.1093/aob/mcl242

Vanden Berghem C (1997) La renouée du Japon en Belgique. Adoxa 15/16:35-38

Verloove F (2002) Ingeburgerde plantensoorten in Vlaanderen, vol 20. Mededeling van het Instituut voor Natuurbehoud, Brussels

Vitousek PM, D'antonio CM, Loope LL, Rejmanek M, Westbrooks R (1997) Introduced species: a significant component of human-caused global change. N Z J Ecol 21:1-16

Voinot IB, Gaillard V, Solviche A (2002) Distribution géographique de la renouée du Japon sur la tête du bassin versant Rhone-

Méditerranée-Corse. Elaboration de stratégies de régulation. In: Journées techniques nationales "renouées". Association Echel, Besançon,

France

Wang R, Wang Y (2006) Invasion dynamics and potential spread of the invasive alien plant species Ageratina adenophora (Asteraceae) in China. Divers Distrib 12:397-408. doi:10.1111/j.1366-9516.2006.00250.x

Weber E (2003) Invasive plants in the world: a reference guide to environmental weeds. CABI-Publishing, London, UK Wilcove DS (1998) Quantifying threats to imperiled species in the United States. Bioscience 48:607-615. doi: 10.2307/1313420 